grave was erected a marble monument ornamented with a star and bearing the names of his great works.

For sixty-one years Laplace lay here, but in accordance with the express wish of his son, in September 1888 his remains were exhumed and reinterred in the grounds of the family estate at Saint Julien de Mailloc, Calvados. The removal seems to have attracted little attention even in scientific circles, and in view of the interest aroused by the centenary of the death of Laplace the following particulars are perhaps worth recording. For them I am indebted to the Comte de Colbert-Laplace, a great grandson of the famous astronomer, who also informs me that on Dec. 11, 1925, a fire completely destroyed the chateau de Mailloc, and with this were lost all the papers and personal relics of Laplace.

Saint Julien de Mailloc is a small hamlet situated between Lisieux and Orbec, Calvados ; and it is on a by-road leading from the main road joining those two places that the tomb of Laplace is to be found. Erected in 1887, it is in the form of a Greek temple about fifteen metres high. The inscriptions recall the birth and death of Laplace, his "Mécanique Céleste," "Système du Monde," and "Théorie Analytique des Probabilités." In a bronze urn in the interior is the heart of Laplace, while the tomb also shelters the remains of his wife, his son, his daughter, and other descendants. Laplace's son, Charles-Emile-Pierre Joseph, Marquis de Laplace, who became a general of artillery, died at the age of eighty-four in 1874, but it was he who desired that Laplace should be brought to Calvados. At the time of the reinterment, the monument which had stood for sixty years in the Pere Lachaise, was given to the commune of Beaumont-enAuge, where Laplace was born, and was re-erected in the cemetery there.

In view of the complete destruction of the papers of Laplace in 1925, it may not be out of place to recall that in NATURE of June $8,1871, p .108$, is a note to the effect that housebreakers raided Laplace's old chateau at Arceuil and threw the manuscript of the "Mécanique Céleste" into the River Bièvre, from which, however, it was rescued.

\section{Science Museum,}

South Kensington, S.W.7.

Tetragonal Structure of Carbon Steel.

IT has been shown by Westgren, Vewer, and many others that the martensite of carbon steel has only the crystal structure of $a$ iron, and sometimes has simultaneous structures of $a$ and $\gamma$ iron with carbon in the state of solid solution. Recently Fink and Campbell (Transactions of the American Society of Steel Treating, 9, 717; 1926) found the body-centred tetragonal structure with a ratio of axes 1.06 in carbon steel ( 1.5 per cent. carbon) after quenching in water from $940^{\circ} \mathrm{C}$. Our investigations of carbon steel quenching in water show also the body-centred tetragonal structure. The following table gives the carbon content, the temperature of quenching $T$, the ratio of axes $c=a / b$, and their dimensions $a$ and $b$ :

\begin{tabular}{|c|c|c|c|c|}
\hline Per cent. & $T .{ }^{\circ} \mathrm{C}$. & $c$. & $a .10^{8} \mathrm{~cm}$. & $b .10^{8} \mathrm{~cm}$. \\
\hline & & & & \\
\hline 0.8 & 1100 & 1.027 & $2 \cdot 851$ & $2 \cdot 920$ \\
1.0 & 1100 & 1.051 & $2 \cdot 843$ & $2 \cdot 987$ \\
1.2 & 1000 & 1.058 & $2 \cdot 848$ & 3.010 \\
\hline
\end{tabular}

In the samples of steel having 0.8 and 1 per cent. carbon in addition to the tetragonal structure were found $\gamma$ iron (in the sample of steel which had 1 per cent. carbon there was no $a$ iron).
From the above table we arrive at the conclusion that the observed tetragonal structure of steel is a solid solution of carbon in the body-centred tetragonal lattice of metal atoms. It is probable that the martensite has always a body-centred tetragonal structure (simultaneously there could be $a$ and $\gamma$ iron). N. SELJAKow. J. KURDUMOFF.

Physico-technical Laboratory, Leningrad, Sosnowka 2.

The Metallurgical Laboratory of

N. Goodtzov.

" Krasnii Putilovetz," Leningrad, Feb. 9.

\section{Early British Patent Grants.}

THE contributor of the "Calendar of Diseovery and Invention " appearing in the pages of NATURE has in the issue for Feb. 26 fallen into a not uncommon error, when he records Mar.-2, 1617, as the date of the first British patent for invention. This certainly is not the case. The reasons that caused the then Commissioners of Patents to start the famous official series of English patents with the year 1617 were purely fortuitous, and in no way endow this particular patent with any special claim to immortality. The researches of Mr. Hulme and others have brought to light a large number of earlier grants, mostly by Elizabeth and James I., but including one (that to John of Utynam for the making of coloured glass) so early as 1449, and it is to this one that the distinction of priority must for the moment be given.

Moreover, the Statute of Monopolies cannot be correctly described as for the first time securing " the sole working or making of any manner of new manufacture within this realm to the true and first in ventor." The Statute was passed simply to prevent the Crown making vexatious monopoly grants; it initiated nothing; and expressly exempted from its operation the use of the existing prerogative in respect of new inventions, a prerogative which, as we have seen, had been constantly exercised for many years past.

The Patent Office Library,

25 Southampton Buildings, London, W.C.2.

\section{Prehistoric Archæology in Yorkshire.}

IN NATURE of Mar. 5, p. 364, announcement is made of the proposed formation of an 'out door' museum at Easington, Yorks, by the East Riding Antiquarian Society. The exhibition of "obsolete farming appliances' is no doubt a praiseworthy object; but one is tempted to inquire when the Mortimer collection is to become accessible for study by those interested in prehistoric archæology? This collection represents the life's work of the late J. R. Mortimer, who excavated a very large number of barrows on the Yorkshire wolds. It ranks with similar collections at Devizes and in the British Museum; but it has not even been seen by most of the present generation of archæologists, including the present writer. The collection is of national importance, and if the people of Yorkshire do not appreciate their good fortune in possessing it, they should hand it over to others who do. A collection in packingcases is of no use to any one.

Ordnance Survey Office, Southampton, Mar. 10.
O. G. S. Crawgord.

No. 2996, VoL. 119] 